\title{
Empirical Investigation of Impediments to Returnees' Entrepreneurship in Ghana: An Application of Structural Equation Modelling
}

\author{
Ibrahim Issifu \\ Graduate School of International Development, \\ Nagoya University, Japan
}

Doi: $10.2478 / \mathrm{mjss}-2018-0015$

\begin{abstract}
In recent years the issue of return migration and development has gained the unprecedented attention of practitioners, policymakers, and international organizations. In particular, the International Organization for Migration's assisted voluntary return program seems to be the subject of increasing euphoria and optimism. However, the most overlooked aspect of return migration and entrepreneurship has been the binding constraints facing returnee entrepreneurs in their home countries. Drawing on field survey data, this study examines the impediments to returnees' entrepreneurship in the Ghanaian capital city of Accra using Principal Component Analysis (PCA) and Structural Equation Modeling (SEM) techniques. The results show that only finance appears to be a key impediment, with a direct relationship with returnees' entrepreneurial activities. Further synthesis of the path analysis of this study shows that access to credit and business training could facilitate returnees' foreign acquired financial and human capital into sustainable entrepreneurial activities in Ghana.
\end{abstract}

Keywords: Entrepreneurship, Returnees, Ghana, Impediments

\section{Introduction}

The nexus between returnees' entrepreneurship and economic growth continues to be significant in recent times. In particular, researchers and practitioners in the advanced economies of destination have begun to see return migration as an active tool in the development process of sending countries (Saxenian, 2002; European Commission, 2011; Hausmann and Nedelkoska, 2017). According to Saxenian (2002), return migration has not only promoted economic development by generating new jobs and wealth in the country of origin but also serves as a conveyor belt for the flow of technical and institutional know-how across the world. Therefore, return migration has increasingly become an issue of major interest, as sending countries tend to leverage these gains to stimulate their economic development. The concept of returnee entrepreneurs has become a fashionable term in the migration literature. Indeed, Black et al. (2003) note that returnees' development of small-scale enterprises is often seen as a panacea to poverty reduction in Africa.

Black and Castaldo (2009) arrive at a similar conclusion, indicating that returnees with work experience and savings accumulated while abroad are particularly likely to invest in entrepreneurial activity. Hausmann and Nedelkoska (2017), using Albania Quarterly Labor Force Survey (QLFS) data of 2012-2014, find that return migrants are more entrepreneurial than non-migrants after controlling for socio-demographic characteristics. Returnees are more likely to be self-employed and engage others. Thus, they contribute to economic growth by creating jobs. Similarly, Ammassari (2004) claims that in both Ghana and Côte d'Ivoire returnees who engaged in entrepreneurial activities, especially the highly skilled returnees promote economic growth by creating new businesses and introducing innovative changes in their workplaces. However, these 
celebratory stories of returnees' contributions to entrepreneurship and development in their countries of origin do not tell the entire story. Some field studies carried out on returnees' entrepreneurial activities indicate that they have to struggle in hostile business environments and fight against the odds just to keep their businesses afloat. In comparison to the global situation, the Ghanaian business environment lags behind on many specifications for enhancing entrepreneurship. Ghana is ranked 110 out of 190 economies on the list for ease of doing business (World Bank, 2017).

While anecdotally the impediments to entrepreneurial activities in Ghana have been connected to inadequate managerial skills, insufficient capital, institutional weakness, social trust and an unfavorable business environment, a minimal attempt has been made to examine the binding constraints to returnees' entrepreneurial activities. Furthermore, discussions and debates surrounding the challenges of returnees' entrepreneurial activities are only gleaned from public discourse on the social enterprise landscape with insufficient empirical content. Specifically, very little was found in the literature on the popular entrepreneurial question: What are the impediments that restrict returnees' entrepreneurial activities in Ghana? This issue calls for investigating the transnational field, including for instance institutional forms, social networks and the general economic conditions of the country. A good understanding of the major impediments to returnees who invested in Ghana is an empirical issue, and this study set out to explore the key constraints on returnees' entrepreneurial activities in Ghana intending to formulating smart policies towards enhancing returnees' contributions to economic growth through entrepreneurship.

This study carefully analyzed the key constraints on returnees' entrepreneurial activities in Ghana using field survey data of 240 returnee entrepreneurs. Specifically, the study examines the impact of finance, human capital, electricity and corruption on returnees' entrepreneurial activities. The findings of this study suggest that only finance appears to exert a negative impact on return migrants' business ownership. Also, facilitating networking between returnee entrepreneurs in Ghana and businesses in their former countries of destination could stimulate returnee entrepreneurs who seek economic opportunities in the private sector of Ghana. One interesting finding is that returnees who failed to invest after return regarded inadequate capital as the key constraint in Ghana, followed by insufficient entrepreneurial training.

The paper is divided into five sections: Section 1 deals with the general introduction of the study. Section 2 introduces the country background of Ghana. Section 3 presents a literature review on return migration and various impediments faced by returnees. Section 4 presents the current research methodology and discusses the results of factor analysis and structural equation modeling. Section 5 concludes the paper.

\section{Ghana: A Short Introduction to the Country}

\subsection{Historical and economic background of Ghana}

Ghana is a former British colony in West Africa. The country shares borders with three Frenchspeaking countries. It shares a boundary with Burkina Faso in the north, Cote d'Ivoire lies in the west, and Togo in the east. The country's population in 2012 was 24.9 million and currently stands at 26.9 million in 2014 (World Bank, 2015). The country covers an estimated land area of 238,535 sq. Km. Ghana's economy is ranked the 82nd largest in the world with a total Gross Domestic Product (GDP) of US\$36.0 billion in 2015 and a per capita of US\$1,340.40 (WEF, 2017). Among the Economic Community of West Africa States (ECOWAS), Ghana's economy was ranked the second largest after Nigeria, which accounting for 10.3 percent of total GDP of the sub-region (Alagidede, Baah-Boateng, and Nketiah-Amponsah, 2013). Ghana is well endowed with natural resources such as gold, diamond, bauxites, timber, and cocoa, and the country has roughly twice the per capita income of the poorest economies in the ECOWAS subregion. Politically, Ghana gained independence from British colonial rule in 1957. The country has experienced both civilian and military administrations since becoming independent and is presently under a stable multi-party system. 


\subsection{Historical view on migration trajectory in Ghana}

Human migration has been a key survival strategy for most people in Africa for many centuries (Bjarnesen, 2013; De Bruijn et.al., 2001). Likewise, Ghanaian citizens who emigrate to Europe, North America, and other parts of the world see it as a potential means of acquiring human and financial capital in the destination countries. Currently, the estimated number of international Ghanaian migrants varies from 1.5 million to 3 million (Twum-Baah, 2005; Mazzucato, 2007), which is estimated to be about 10 percent of the population of Ghana. This indicates that approximately half of Ghanaian households have an emigrant and are directly affected by migration. Interestingly, the Ghanaian diaspora is very widely dispersed.

In the annals of Ghanaian out-migration, the 1970s to 1980s represent critical moments. Emigration from Ghana on a large scale started gradually in the late 1960s and increased speedily in the mid-1970s to the 1980s. These trends were also reflected in the recent flows of remittances to Ghana. The flow peaked in 2012 at about US $\$ 2.5$ billion and fell to US\$2.3 billion in 2014 . The International Organization for Migration (IOM) (2017) observes that remittances nearly doubled household income in 2016.

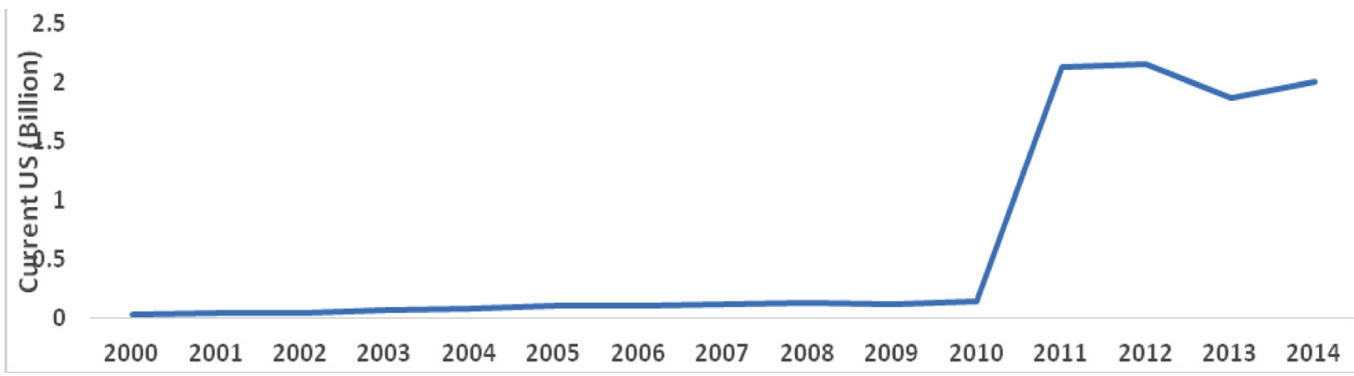

Figure 1. Inflows of remittances to Ghana 2000-2014

Source: World Bank, 2015

Return migration is a significant part of the cycle of migratory movement in Ghana. The country's Living Standards Measurement Survey (GLSS) of 1998/9 claims that the number of return migrants overall had ballooned to 16 percent (Asenso-Okyere et al. 2000). Since the mid-1990s most studies have observed an increasing number of returnees to Ghana as a result of the significant improvement in the Ghanaian economy (Twum-Baah, 2005; IOM, 2009) as well as economic optimism spurred by oil discovery in 2007 (McCaskie, 2008).

\section{Review of Empirical Literature}

\subsection{Defining return migration}

The use of the term return migration dates back several years; however, it has attracted less scholarly attention than other aspects of migration (De Haas, 2010; Lucas, 2005). The initial silence over return migration in the literature may be due to the notion that every migration stream creates a counter-stream, as proposed by Ravenstein (1885). This indicates that return migration is not an option in any migration processes. Return migration to West African countries is a recent phenomenon due to restored political stability and improved economic opportunities (Anarfi and Jagare, 2005). Return migration is often seen as the returning of an individual to his/her country of origin after spending a year or more in the host country (The International Organization for Migration, 2004). In this study, a return is seen as a partial return to a location where the migrants once resided. Therefore, most of the returnee entrepreneurs in the field survey used in this study should be regarded as circular migrants or transnational returnees. 


\subsection{Taking a close-up view of the impediments to returnees' entrepreneurship in Ghana}

The state of policy debates on returnees' entrepreneurship in the development of the home country is still a matter of considerable controversy among migration scholars and decision makers. At the empirical level, while some studies posit that return migration can stimulate business start-ups (see Marchetta, 2012; Dustmann and Kirchkamp, 2002), studies such as de Haas (2010) contend that the development potential of return migration depends on the general conditions in the home country. This section systematically examines the various impediments documented in the literature as factors influencing returnees' entrepreneurship.

Many empirical studies point to the significance of financing constraints on entrepreneurship activity. Using a reduced-form study, Paulson and Townsend (2004) investigate how liquidity constraints influence business in Thailand. The findings show that financial obstacles shape the patterns of entrepreneurship. Specifically, well-off families are more likely to initiate businesses. Moreover, Mesnard (2004) examines the effect of credit constraint on return migrants in Tunisia using a life-cycle maximization model. She finds that there is liquidity constraint among migrant entrepreneurs, and those who receive financial credits to invest after return do not often return to their former residence in their destination countries. Empirical studies such as that conducted by Naudé (2008) have indicate that the quality and quantity of self-employment in a particular country or region depend on the relative rates of return to being entrepreneur and obstacles such as credit market imperfections and start-up costs. The effect of financial liquidity on returnees' entrepreneurship, however, is theoretically unclear. Dumont and Spielvogel (2008) argue that returnees can save to finance an entrepreneurial activity in the country of origin. From this perspective, individuals make a common choice that may be stylistically described as combinations of migration, savings, return, and investment. In the same vein, Woodruff and Zenteno (2007) use about 6000 small firms located in urban areas of Mexico to estimate the relationship between migration and entrepreneurship. They observe that returnees' resources helped to unleash the entrepreneurial spirit of microenterprises through business capital injection. Thus, an attempt is being made to shed some empirical light on these ambiguities and debates that surface in the literature.

The availability of sound human resources contributes to the efficient functioning of entrepreneurial activities. High human capital improves entrepreneurial performance by innovating products and processes, reducing transaction costs and increasing investment (Mountford, 1997; Grossman and Hart, 1986). Conversely, low human capital increases transaction costs for all entrepreneurs and creates a barrier to entrepreneurial activity. Many studies indicate that personal migration experience has the potential to enhance the acquisition of human capital which might be relevant to the home country. For instance, Gubert, De Vreyer and Robilliard (2007) show that the average length of schooling among return migrants from the Organization for Economic Cooperation and Development (OECD) nations is 11 years, which is double that of return migrants from non-OECD countries as well as non-migrants. Specifically, De La Barre (2007) opines that 16 percent of returnees to Cape Verde had a higher professional degree, while for non-migrants it was only about 1 percent. Similar effects are observed in most developing nations, such as Egypt (Marchetta, 2012) and Albania (Piracha and Vadean, 2010). However, human capital gains may be less useful if the skills acquired by the migrants cannot be transferred (Mattoo, Neagu, and Özden, 2008). Besides, in Europe, African migrants are overrepresented in unskilled jobs (De Haas, 2006; Schiff and Özden, 2006; Schoumaker et al. 2013). This implies that African returnees may have limited access to better human capital. While these studies examine different constraints to returnee entrepreneurial activities, they usually pay attention to a small subset of widely characterized impediments.

Inadequate infrastructure is identified as a critical constraint to entrepreneurial activity in most developing countries, and for the diagnostic approach suggested by Hausmann, Klinger, and Wagner (2008) unreliable power supplies can exert a significant challenge in the energy-intensive manufacturing sector. Infrastructure-related impediments result in increased costs and create barriers to productive opportunities for businesses (World Bank Enterprise Survey, 2013). Across Africa, the power supply is a particularly underdeveloped, as evidenced by the rampant power 
crises recorded in 2015 and 2016 in many African countries, including Ghana, Nigeria, Kenya, and South Africa (World Economic Forum, 2017). Anecdotal evidence and the opinions of well-informed people have shown that unreliable supply of power, poor service quality and the high cost of tariffs were identified as the top obstacles to entrepreneurial activity in most countries in Africa. Dollar et al. (2005) use a survey to assess the various business conditions in China, India, and Pakistan and observe that a firm's growth rates are influenced by critical environmental factors such as insufficient electricity which tend to affect entrepreneurial activities negatively. In contrast, O'Brien et al. (2017) observe that Albania has experienced low costs of electricity for businesses, but the country has not experienced a significant growth rate. This may imply that electricity is not a key obstacle to growth in Albania and that continued improvements in the provision of electricity alone will be unlikely to stimulate growth.

Corruption in its various forms is perceived to be inimical to entrepreneurial activity. Corruption by government officials may create an unattractive business environment by raising the risks and costs associated with conducting business. In an analysis of the effects of bribe on firms' growth in the Caribbean and Latin America regions, Seker and Yang (2012) report that the firms that pay bribes for electricity, water connections and permits grow 23.6 percent less than the firms without bribes payments. This suggests that corruption decreases the number of business establishments as well as overall entrepreneurial activities. Hamilton and Hudson (2014) contend that in Sudan, people of lower social standing are more vulnerable to being asked for a bribe. Although these studies investigate the effect of corruption on doing business, far too little interest has been shown in consequence of corruption on returnees' entrepreneurial activities. These findings are particularly interesting if one keeps in mind that Plaza and Ratha (2011) observe that the key to attracting contributions from migrants is trust in the government at home, a sound business environment, and low levels of red tape. Generalized trust is particularly relevant for returnee entrepreneurs since anecdotal evidence show that overseas migration may lead to a loss of social capital back home. However, so far, the impact of corruption or trust on returnee entrepreneurial activity is largely unclear.

\section{Methodology}

\subsection{The survey data type and sampling}

To examine the constraints faced by returnees who engaged in entrepreneurial activities in Ghana, a field survey was conducted in March-April of 2017. The field survey was administered through a structured questionnaire to households with returnees living in the Greater Accra region of Ghana. In all, the questionnaire was administered to a total of 260 respondents, out of which 240 of the questionnaires (consisting of data on both returnees who invested and those who did not invest in business after return) were used for the descriptive statistics after the data cleaning process. This indicates a valid response rate of approximately $92 \%$. In addition, out of 240 returnees, data on 180 returnees who invested in business after return were used in the econometric analysis. This is because the study intends to find out the challenges encountered by returnees who established businesses in Ghana. Also, when responding to the questionnaire survey, the survey focuses on returnee entrepreneurs who had been operating their businesses in Ghana for at least one year.

The data provide information on returnees' households socio-demographic characteristics, educational level, reasons for return, reasons for not carrying out business investment, as well as impediments encountered in business ownership in Ghana. This detailed and rich data help my efforts to identify the myriad of challenges faced by returnee entrepreneurs in Ghana. However, since the survey targeted returnees only, the question of whether the entrepreneurial challenges of returnees differ from those of stayers cannot be explored.

The field survey questionnaire was designed based on a comprehensive literature review, logic and corrections from the field work. The response items are captured on five- point (1-5) Likert scales, in which 1 shows that respondent confirms the statement to be the "most important" factor and 5 shows that the respondent thinks the statement is "not important" factor respectively. The study was conducted in the Greater Accra region of Ghana, the administrative and vibrant 
economic region of the country. Work by Beauchemin (2012) finds evidence that the Greater Accra region constitutes a sizeable proportion of the country's population and it is one of the regions with a high prevalence of both out-migration and return in Ghana. A strand of the migration literature indicates that most migrants tend to work primarily in cities in their destination countries (Ravenstein, 1885). Hence, most returnees will prefer to work in similar urban conditions upon return, where they can easily undertake their economic activities. Therefore, Accra becomes the ideal location for their business.

A two-stage sampling approach was adopted as the data gathering instrument; the first stage consisted of sampling at the district level. Here a simple random sample was used to select the districts and municipalities. The second phase involved the selection of the households from the sampled district, given that it is hard to identify households that have returnees; I adopted snowballing and word of mouth techniques to determine households with returnees. This was possible because of the level of social integration prevalent in Ghana. As Nugent (1995) aptly observes, social positions are vital for social interactions in Ghana.

\subsection{Structural equation model(SEM)}

Using the basic systems of structural equations proposed by Jöreskog and Sörbom, (2003). My conceptual model presented below contains latent variables or constructs. Latent variables in this study refer to those circumstances that are believed to exist but remain unobservable (Oud and Folmer, 2008). These latent constructs are measured through the respondent's response towards a set of items in a questionnaire. Usually, SEM permits the handling of observed and latent variables in their relationships within a unified structure (Jöreskog and Sörbom, 2003). Jöreskog and Sörbom (1982) observe that SEM can be expressed in two sub-models: a structural model and measurement model. The structural model describes the relationships between endogenous constructs and the exogenous constructs as well as the connections among the endogenous constructs, while the measurement model indicates the relationships between the observed indicators and the latent variables. The econometric equations below show the measurement models for the endogenous and exogenous constructs, respectively.

$$
\begin{array}{ll}
y=\Lambda_{y} \eta+\mathcal{E} & 1 \\
x=\Lambda_{x} \xi+\delta & 2
\end{array}
$$

where: $y$ denotes a $p \times 1$ vector of dependent variables or observed endogenous constructs, $x$ represents a $\mathrm{q} \times 1$ vector of independent variables or observed exogenous constructs, $\eta$ is an $\mathrm{m} \times$ 1 vector of latent endogenous constructs, and $\xi$ is an $n \times 1$ vector of exogenous constructs. $\wedge y$ and $\Lambda x$ are $p \times m$ and $q \times n$ matrices of coefficients respectively. Lastly, $\varepsilon$ and $\delta$ are $p \times 1$ and $q \times 1$ vectors of errors in measurement of $y$ and $x$, respectively. I estimate the structural model as follows: $\eta=\mathrm{B} \eta+\Gamma \xi+\zeta$

where $\eta$ and $\xi$ are described in equations (1) and (2), B is an $\mathrm{m} \times \mathrm{m}$ matrix with $\beta \mathrm{ij}$ indicating the impact of the jth endogenous constructs on the ith endogenous construct. $\Gamma$ is an $\mathrm{m} \times \mathrm{n}$ matrix with yij describing the impact of the jth exogenous constructs on the ith endogenous constructs and $\zeta$ is an error term. The model was estimated using the Stata 13.1 software, though LISREL and SEPATH are other software packages than can equally be utilized (Kline, 2005). Also, maximum likelihood (ML) estimation technique was chosen over other parameter estimation techniques (asymptotically distribution-free (ADF), two-stage least squares, weighted least squares) since the problem of missing data can be addressed (Arbuckle, 1999; Muthén and Muthén, 1998).

\subsection{Data analysis and results}

To design effective policies to facilitate returnee entrepreneurship, it is crucial to have a fair knowledge of the characteristics of returnees as well as their experience acquired abroad. The respondents in the field survey, as shown in Table 1, are composed of $61 \%$ male and $39 \%$ female; these respondents range in age from 15 years to over 65 years. Most of the respondents, however, were found to be in the age bracket of 35-44 years old, followed by the $25-34$ bracket, with $32 \%$ 
and $28 \%$ respectively. Concerning their level of education, close to $25 \%$ had attained first degrees or higher, while a small percentage $(6.6 \%)$ had no formal education. Also, it was found that most of the returnees had a professional and technical level of education, followed by those with first degree or higher. These findings thus mean that most of the returnees have some significant level of formal education. This perhaps points to the possibility of brain-gain in Ghana. The sociodemographic characteristics of returnees are set out in Table 1.

Table 1. Socio-demographic characteristics of returnees

\begin{tabular}{|c|c|c|c|}
\hline & & Freq. & Percent \\
\hline & Male & 147 & 61.0 \\
\hline \multirow[t]{4}{*}{ Gender } & Female & 93 & 39.0 \\
\hline & Total & 240 & 100.0 \\
\hline & $15-24$ & 24 & 10.0 \\
\hline & $25-34$ & 68 & 28.3 \\
\hline \multirow{6}{*}{ Age at return } & $35-44$ & 76 & 31.7 \\
\hline & $45-54$ & 60 & 25.0 \\
\hline & over 65 & 12 & 5.0 \\
\hline & Total & 240 & 100.0 \\
\hline & None & 16 & 6.6 \\
\hline & Primary/Basic & 33 & 13.9 \\
\hline \multirow[t]{5}{*}{ Returnee's level of education } & Senior High School/O/A level & 52 & 21.7 \\
\hline & Professional/Technical & 79 & 32.8 \\
\hline & Bachelor degree/Higher & 60 & 25.0 \\
\hline & Total & 240 & 100.0 \\
\hline & Sound business environment & 110 & 46.0 \\
\hline \multirow{4}{*}{ Main reasons for the return } & End of study/training & 36 & 15.0 \\
\hline & Starting a business at home & 82 & 34.0 \\
\hline & Others (health reasons, etc.) & 12 & 5.0 \\
\hline & Total & 240 & 100.0 \\
\hline \multirow{3}{*}{ Business ownership } & Returnees who owned business & 180 & 75.0 \\
\hline & Returnees who didn't own business & 60 & 25.00 \\
\hline & Total & 240 & 100.0 \\
\hline \multirow{5}{*}{$\begin{array}{l}\text { Sector of returnees' } \\
\text { business } \\
\text { investment }\end{array}$} & Food and nutrition & 52 & 21.6 \\
\hline & Services (ICT, Finance, etc.) & 82 & 34.2 \\
\hline & Light manufacturing & 46 & 19.2 \\
\hline & None & 60 & 25.0 \\
\hline & Total & 240 & 100.0 \\
\hline \multirow{4}{*}{ Reasons for not carrying out any investment } & Lack of capital & 43 & 71.7 \\
\hline & Lack of entrepreneurship training & 12 & 20.0 \\
\hline & Others & 5 & 8.3 \\
\hline & Total & 60 & 100.0 \\
\hline
\end{tabular}

Source: Field survey, 2017

\subsection{Factor analysis for the impediments construct}

For the sake of understanding the binding constraints on the returnees' entrepreneurship in Ghana, this study initially performs the CFA to examine the factor loadings of the impediments constructs (such as access to credit, electricity, corruption, and management) and to examine the model fit. As shown in Table 2, for the first construct, the Kaiser-Meyer-Olkin measure of sampling adequacy was 0.58 , and Bartlett's test of sphericity was significant $\left(\chi^{2}=33.6, p<.05\right)$. Kaiser (1974) suggests 0.60 s or above as the acceptable value of sampling adequacy or factorial simplicity. The results for the communalities scores were never below 0.3 , and this confirms that each of the variables shared some variance with other variables. Based on this rule of thumb, factor analysis was estimated with the four variables.

For each of the constructs, I used PCA since the purpose was to identify and compute 
composite scores for the factors underlying each of the constructs measured. Unique to the impediment (IR) construct, the results from Table 2 indicate that the initial Eigenvalues for the factor explained about $37 \%$ of the variance, whereas the second factor explained $26 \%$ of the difference. The factors extracted were assessed using a varimax rotation of the factor loading matrix. Cumulatively, the two-factor solution explained $63 \%$ of the variance. The study also considered the oblimin rotation for the factor analysis, and the outputs obtained for each construct was not entirely different; hence varimax rotation was used for the final solution.

For the IR construct, no items were dropped from the factor analysis process since all were loading high under each of the two extracted factors. Besides, all had initial loadings over 0.5 . Table 3 shows the two factors obtained from the impediments scale of items, and the first factor associated with external impediment has three-factor loadings $(0.73,0.68$ and 0.69 respectively). The second factor relates to an internal impediment, which had only a one-factor loading value of 0.941 . This indicates a substantial loading of the item. The results of the PCA show that the underlying constructs explain close to $63 \%$ of variance in the scale. Similarly, the Kaiser-MeyerOlkin (KMO) value of 0.58 was significant. The results obtained from the preliminary analysis of the impediments to returnee entrepreneurial activities in Ghana are presented in Table 2, whiles Table 3 shows the factor loadings and communalities impediments to returnees' entrepreneurial activities.

Table 2. The results of the initial solution on impediments to returnees' entrepreneurship

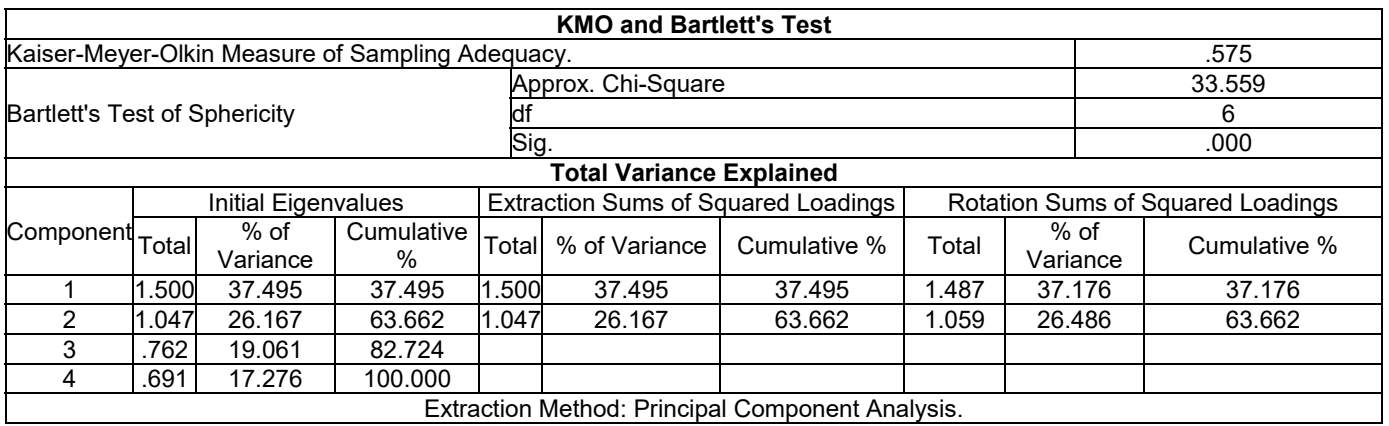

Source: Field survey, 2017

Table 3. Factor loadings of 4 items for impediments to returnees' entrepreneurship $(N=180)$

Rotated Component Matrix ${ }^{a}$

\begin{tabular}{lccc}
\hline & \multicolumn{2}{c}{ Component } & \\
\cline { 2 - 3 } & $\begin{array}{c}\text { External } \\
\text { constraint }\end{array}$ & $\begin{array}{c}\text { Internal } \\
\text { constraint }\end{array}$ & Communalities \\
\hline Inadequate credit (IR1) & -.730 & & .614 \\
Challenges of corruption (IR2) & .688 & & .561 \\
Inadequate electricity (IR3) & .693 & .484 \\
Management challenges (IR4) & & .941 & .887 \\
Extraction Method: Principal Component Analysis. & & & \\
Rotation Method: Varimax with Kaiser Normalization. & & \\
a. Rotation converged in 3 iterations. & & \\
\hline
\end{tabular}

Note: The communality is the proportion of variation in a variable explained by all other variables.

Source: Field survey, 2017

\subsection{Factor analysis for the policy construct}

Table 4 shows the results of factor analysis output for the policy construct. The total of a 5 -item scale was used to measure the underlying constructs. I find evidence in Table 4 indicating that the 
$\mathrm{KMO}$ measure of sampling adequacy was 0.65 , and this value was 0.05 higher than the acceptable value of 0.6 ; additionally, the result of Bartlett's test of sphericity was significant $\left(\chi^{2}=231.04, p<\right.$ 0.05 ). The results for the communalities scores were all above 0.3 , and this confirms that each of the items had some common variance with other items. Based on these statistics, factor analysis was conducted for the policy construct (PEC) using five items. Also, the principal component analysis was used to identify and compute composite scores for the factors underlying each of the policy constructs measured.

For the policy construct (PEC) the findings indicate that the initial Eigenvalues for the factor explained about $49.8 \%$ of the variance, whereas the second factor explained $20.2 \%$ of the variance. The factors extracted were investigated using a varimax rotation of the factor loading matrix. Cumulatively, the two-factor solution accounted for $70.1 \%$ of the common variance.

As was the case of the IR construct, no items were dropped from the factor analysis steps since for the policy construct. All factors loaded high under each of the two extracted elements. Using principal-components factor were extracted based on varimax rotation. Table 5 shows the estimation results of the factor loading matrix for the final solution. The results indicate that all items are loading high (i.e., loadings were over 0.5). Two items loaded high under the "Policy 1" construct and three under the "Policy 2". Finally, the PCA shows that the underlying constructs explain approximately $70 \%$ variance in the scale. Similarly, the KMO value of 0.65 is significant. Table 4 provides the breakdown of policy construct for returnees' entrepreneurship in Ghana. Also, Table 5 presents the factor loadings of 5 items for policy construct.

Table 4. The initial results of Policy construct on returnees' entrepreneurship

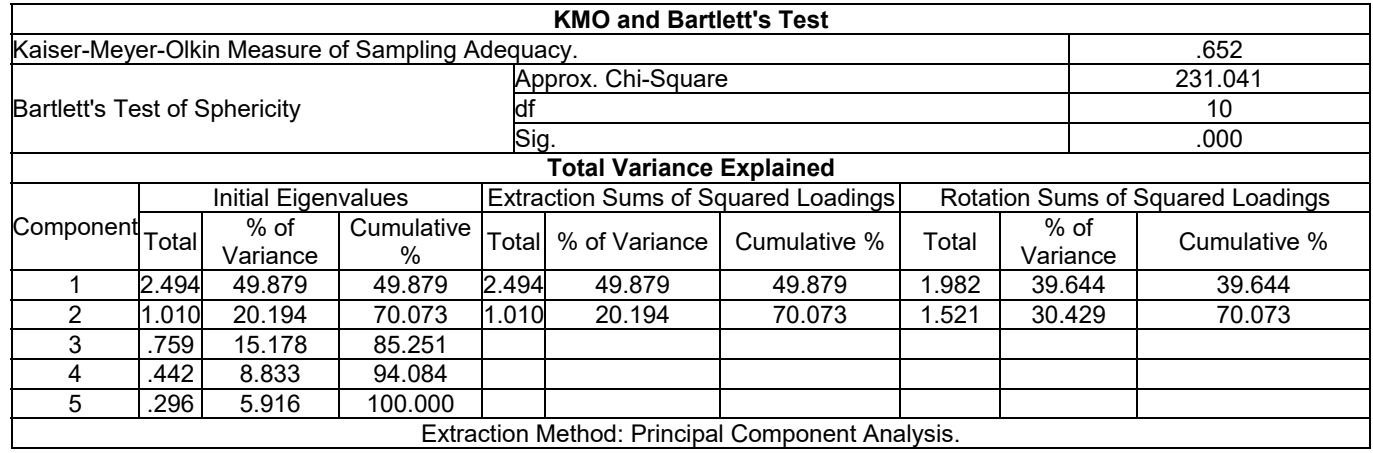

Source: Field survey, 2017

Table 5. Factor loadings of 5 items for Policy Construct (PEC) $(\mathrm{N}=180)$

\section{Rotated Component Matrix ${ }^{\mathrm{a}}$}

\begin{tabular}{|c|c|c|c|}
\hline & \multicolumn{2}{|c|}{ Component } & \multirow[b]{2}{*}{ Communalities } \\
\hline & $\begin{array}{c}\text { Policy } \\
1\end{array}$ & $\begin{array}{l}\text { Policy } \\
2\end{array}$ & \\
\hline $\begin{array}{l}\text { Enhance access to credit via partnership with the private financial sector } \\
\text { and government-sponsored schemes) (PEC1) }\end{array}$ & -.745 & & 689 \\
\hline Support business counseling (PEC2). & & -.887 & .787 \\
\hline Establish a joint returnee/government decision-making council (PEC3). & & .800 & .735 \\
\hline Match local business leaders with returnee entrepreneurs (PEC4). & & .648 & .486 \\
\hline Support entrepreneurship training (PEC5). & .897 & & .807 \\
\hline Extraction Method: Principal Component Analysis. & & & \\
\hline $\begin{array}{l}\text { Rotation Method: Varimax with Kaiser Normalization. } \\
\text { a. Rotation converged in } 3 \text { iterations. }\end{array}$ & & & \\
\hline
\end{tabular}

Note: The communality is the proportion of variation in a variable explained by all other variables.

Source: Field survey, 2017 


\subsection{Factor analysis for the facilitation construct}

The results presented in Table 6 represent the factor analysis output for the facilitation of returnees' entrepreneurship in Ghana. For this construct, a 2-item scale was used to measure the underlying constructs. The KMO measure of sampling adequacy was 0.50 ; this value was found to be below the recommended value of 0.6. Additionally, the result for the Bartlett's test of sphericity is significant $\left(\chi^{2}=10.81, p<.05\right)$. The estimation results for the communalities scores are all above 0.3. The communality results are indicative that each of the items in the scale shared some common variance with other items. The principal component analysis is utilized to identify and compute composite scores for the factors underlying each of the facilitation construct (FC).

For the facilitation construct (FC), the findings indicate that the initial Eigenvalues for the factor explained about $62.6 \%$ of the variance, whereas the second factor explained $37.4 \%$ of the common variance. Cumulatively, the two-factor solution accounted for $62.6 \%$ of the difference. Like the other construct, the decision to use varimax rotation was based on a comparison of the findings obtained from both varimax and oblimin rotations respectively. Based on the outputs obtained for each of the rotations, the varimax rotation was used for the final solution since there was not much variation in the results. In other words, the varimax rotation produced the best defined-factor design.

Using the principle-components factor extracted based on varimax rotation, the factor loadings presented in Table 7 show that two items were loading high above 0.5. Only one factor was obtained, as shown in the table. Specifically, the findings show that the two items measured access to credit and business training in promoting entrepreneurship among returnees. The factor loadings for each item was 0.791 , indicating a heavy loading. This is shown in the total variance explained in Table 7.

Table 6. The initial results of Facilitation construct for returnees' entrepreneurship

\begin{tabular}{|c|c|c|c|c|c|c|}
\hline \multicolumn{7}{|c|}{ KMO and Bartlett's Test } \\
\hline \multicolumn{6}{|c|}{ Kaiser-Meyer-Olkin Measure of Sampling Adequacy. } & .500 \\
\hline \multirow{3}{*}{\multicolumn{3}{|c|}{ Bartlett's Test of Sphericity }} & \multicolumn{3}{|c|}{ Approx. Chi-Square } & 10.815 \\
\hline & & & \multirow{2}{*}{\multicolumn{3}{|c|}{\begin{tabular}{|l} 
df \\
Sig.
\end{tabular}}} & 1 \\
\hline & & & & & & .001 \\
\hline \multicolumn{7}{|c|}{ Total Variance Explained } \\
\hline \multirow{2}{*}{ Component } & \multicolumn{3}{|c|}{ Initial Eigenvalues } & \multicolumn{3}{|c|}{ Extraction Sums of Squared Loadings } \\
\hline & Total & $\%$ of Variance & Cumulative \% & Total & $\%$ of Variance & Cumulative \% \\
\hline 1 & 1.252 & 62.612 & 62.612 & 1.252 & 62.612 & 62.612 \\
\hline 2 & .748 & 37.388 & 100.000 & & & \\
\hline
\end{tabular}

Source: Field survey, 2017

Table 7. Factor loadings of 2 items for facilitation construct (FC) $(N=180)$

\section{Component Matrix}

\begin{tabular}{|c|c|c|}
\hline & $\begin{array}{c}\text { Component } \\
\text { Effectiveness }\end{array}$ & Communalities \\
\hline $\begin{array}{l}\text { The effective use of educational qualifications achieved overseas for } \\
\text { entrepreneurship can be improved by supporting the credit needs of returnee } \\
\text { entrepreneurs (FC } 1 \text { ). }\end{array}$ & .791 & .626 \\
\hline $\begin{array}{l}\text { Effectiveness of foreign savings in promoting business investment can be } \\
\text { enhanced by supporting business training of returnee entrepreneurs (FC } 2 \text { ). } \\
\text { Extraction Method: Principal Component Analysis. } \\
\text { a. } 1 \text { components extracted. }\end{array}$ & .791 & 626 \\
\hline
\end{tabular}

Note: The communality is the proportion of variation in a variable explained by all other variables.

Source: Field survey, 2017

\subsection{The estimated SEM}

Regarding model fit, Kaplan (2000) and Hooper et al. (2008) provide detailed guidelines and 
discussions on various goodness-of-fit indicators to determine an appropriate model fit. Some standard fit indexes are the chi-square goodness of fit (GFI), the normed fit index (NFI), the root means squared error of approximation (RMSEA) and comparative fit index (CFI). However, there is other known goodness of fit approaches that are also used in the SEM framework, and these include Bayesian information criterion (BIC), Akaike's information criterion (AIC) and coefficient of determination (CD). In most empirical studies, the chi-square, the standardized root means square residual (SRMR), the GFI, and RMSEA are widely used. I used some of the indexes in this study to assess the consistency of the model fitness concerning the different model fitness measures.

Table 8 presents the results of the goodness of fit for the SEM estimation. Overall, the goodness-of-fit indicators for the SEM model seem to meet their critical values, suggesting that the model appears to be a good fit. For instance, Bollen (1989) observes that the normed chi-square values of 2.0,3.0, or even 5.0 have been confirmed as indicating acceptable fit. I did not perform posthoc modifications due to the satisfactory fit of the data to the hypothesized model.

Table 8. Overall measures of goodness of fit

\begin{tabular}{|l|c|}
\hline Indexes & Values \\
\hline Chi-square with 95 degree of freedom & 455.46 \\
\hline Normed chi-square (ChiSq/df) & 3.00 \\
\hline Root mean square error of approximation (RMSEA) & 0.206 \\
\hline Comparative fit Index (CFI) & 0.440 \\
\hline Standardized root mean square residual (SRMR) & 0.167 \\
\hline Turker-Lewis index (TLI) & 0.269 \\
\hline Coefficient of determination (CD) & 0.995 \\
\hline
\end{tabular}

Source: Field survey, 2017

\subsection{The measurement model}

Table 9 shows the estimation findings for the measurement model, coefficients of latent variables and the respective standard errors for each of the final measurement equations. In this table, the reliability score represented by the r-square $\left(R^{2}\right)$ was lowest for observed variables ER1, PEC4, and PEC1 with scores of $0.22,0.30$, and 0.47 respectively. However, the remaining variables had high scores above 0.5 , and the highest observed variables with a value of 0.76 were ER2, FC1, and FC2. The R-squared indicates the percentage of difference of the indicator in explaining the underlying construct being measured. Therefore, I can safely state that the ER2, FC1, and the FC2 score of 0.76 shows the most reliable indicators and the least is ER1, which had a rating of 0.22 . Therefore, for the construct returnees' entrepreneurial indicator, ER2 gives a better measure compared with indicator ER1. Similarly, I noticed that indicator IR4 better explains the underlying constructs internal, for external constraint, indicators IR3 and IR2 were found to measure the construct better.

Table 9. Measurement model

\begin{tabular}{|l|c|c|c|c|}
\hline Latent Variable & Indicator & Coefficient & Standard Error & $\mathbf{R}^{2}$ \\
\hline \multirow{2}{*}{ Returnees' Entrepreneurial Activities (REA) } & ER1 & 0.47 & 0.09 & 0.22 \\
\cline { 2 - 5 } & ER2 & 0.87 & 0.13 & 0.76 \\
\hline \multirow{3}{*}{ External constraint } & IR1 & 0.41 & 0.14 & 0.63 \\
\cline { 2 - 5 } & IR2 & -0.80 & 0.22 & 0.64 \\
\cline { 2 - 5 } & IR3 & -0.11 & 0.09 & 0.65 \\
\hline Internal constraint & IR4 & 0.50 & 66.83 & 0.65 \\
\hline \multirow{2}{*}{ Policy 1 } & PEC1 & 0.62 & 0.07 & 0.47 \\
\hline \multirow{3}{*}{ Policy 2 } & PEC5 & -0.73 & 0.07 & 0.54 \\
\hline \multirow{2}{*}{ Facilitation } & PEC2 & 0.77 & 0.08 & 0.59 \\
\cline { 2 - 5 } & PEC3 & -0.72 & 0.08 & 0.59 \\
\cline { 2 - 5 } & PEC4 & -0.55 & 0.07 & 0.30 \\
\hline & FC1 & 0.87 & 0.14 & 0.76 \\
\cline { 2 - 5 } & FC2 & 0.27 & 0.09 & 0.76 \\
\hline
\end{tabular}

Source: Field survey, 2017 


\subsection{The structural model}

The empirical hypothesis of the SEM model is outlined graphically in Figure 2. Ovals represent the latent variables derived from a factor analysis (see Tables 3, $5 \& 7$ ) and the rectangles represent observed or measured variables. I conducted SEM analysis based on Likert-scale survey data from 180 returnees who owned businesses in Ghana's capital, Accra. In this study, structural modeling was appropriately selected; not only can it efficiently analyze multiple indicators for each of the latent constructs (Wang and Staver 2001), but it can also add the mediating variable in a model and examine its impact (Zainudin and Jusoff 2009). The estimated structural model coefficients, standard errors and R-squares $\left(R^{2}\right)$ are presented in Table 10 . The findings indicate that there is a significant relationship between policy 1 and facilitation. Again, the study found that stand-alone policies of 1 and 2 were negative but did not have significant effect on returnees' entrepreneurial activities. For the impediments constructs, the results show that external impediments had a significant adverse effect on returnees' businesses in Ghana. The implication, therefore, is that the non-existence of these policies invariably will negatively influence the entrepreneurial initiatives of the returnees in the study area. The policy variable (1) in Table 10, was significant at a $1 \%$ level of significance, indicating that access to credit and business training can help in the facilitation of return migrants' investments in the country. The apriori expectation was also met.

Table 10. The final structural model (Standardized coefficients)

\begin{tabular}{|l|c|c|}
\hline Details & FC & REA \\
\hline Facilitation (FC) & & $1.31(1.79)$ \\
\hline Policy 1 & $0.788^{\star \star *}(0.137)$ & $-0.75(1.39)$ \\
\hline Policy 2 & & $-0.03(.095)$ \\
\hline External constraint & & $-1.28^{\star *}(.591)$ \\
\hline Internal constraint & & $0.111(29.86)$ \\
\hline Returnee Entrepreneurial Activities (REA) & $\mathbf{0 . 7 3}$ & \\
\hline $\mathrm{R}^{2}$ & $\mathbf{0 . 8 5}$ \\
\hline
\end{tabular}

Note: Standard errors in parentheses, *,**,*** show significant at $1 \%, 5 \%$, and $10 \%$ levels, respectively

Source: Field survey, 2017

\subsection{Indirect and total effects}

Schreiber et al. (2006) suggest that discussion of the findings of a structural model is half-done without deliberation of indirect effects and the coefficients of determination. This view is supported by Jöreskog and Sörbom (1982), who wrote that the indirect effect of a variable in SEM describes the impacts of an endogenous variable through intervening endogenous variables. Jöreskog and Sörbom (1982) conclude that the total effects, represents the summation of the direct and indirect effects. In this regard, Kline (2005) indicates that indirect effects are estimated as the product of direct effects, either unstandardized or standardized results. I computed the standardized and indirect effects as parts of the final model, and the results are shown in Table 11. You can see the mediating or facilitation (FC) variable with a total effect computed value of 1.3 , positive but not statistically significant. Again, the response variable IR1 has a total impact score of negative 1.28 on the returnees' entrepreneurial activities (REA) variable. The policy (PEC1) construct had a significant positive overall effect on returnee's entrepreneurial activities. Also, you can see a positive significant total effect of the policy (PEC1) construct on the facilitation construct; this leads to a total effect value of 0.78 . The indirect effect link was between policy 1 through facilitation(FC) which recorded a positive score of 1.04 but was not statistically significant. 
Table 11. Direct, indirect and total effect (final standardized results)

\begin{tabular}{|c|c|c|c|c|c|}
\hline \multirow{2}{*}{ Variables } & \multicolumn{2}{|c|}{ Direct Effect } & Indirect Effect & \multicolumn{2}{c|}{ Total Effect } \\
\cline { 2 - 6 } & FC & REA & REA & FC & REA \\
\hline FC1 & & $1.31(1.79)$ & & & $1.3(1.79)$ \\
\hline PEC1 & $0.788^{\star * *}(0.137)$ & $-0.75(1.39)$ & $1.04(1.415)$ & $0.788^{* * *}(0.137)$ & $0.28^{\star * *}(0.117)$ \\
\hline PEC2 & & $-0.03(0.095)$ & & & $-0.03(0.096)$ \\
\hline IR1 & & $-1.28^{\star *}(0.591)$ & & & $-1.28^{* \star}(0.591)$ \\
\hline IR2 & & $0.111(29.86)$ & & & $0.11(29.86)$ \\
\hline
\end{tabular}

Note: Standard errors in parentheses, $*, * *, * * *$ show significant at $1 \%, 5 \%$, and $10 \%$ levels, respectively.

Source: Field survey, 2017

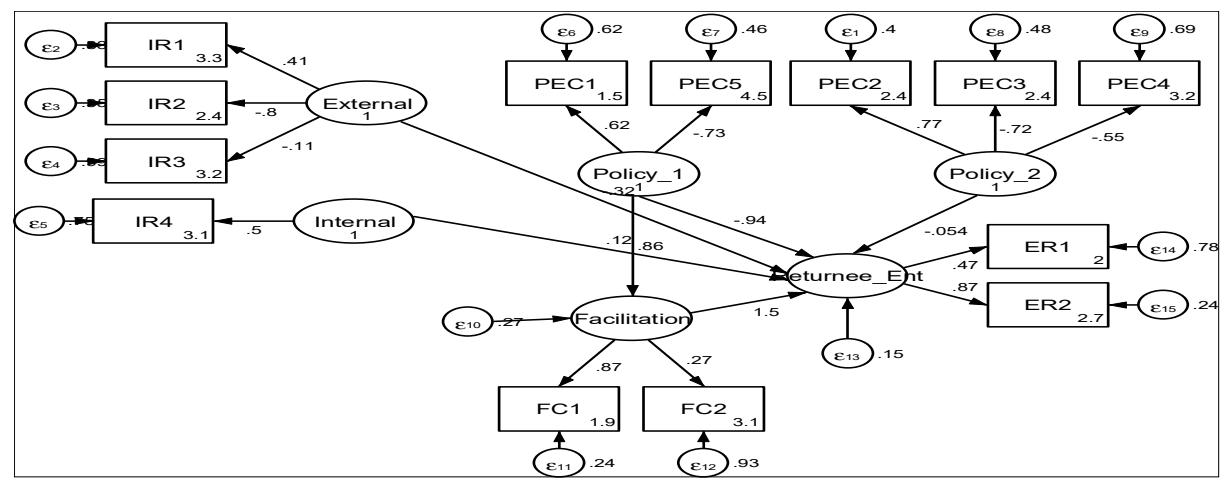

Notes: ER1=Remittances, ER2=Social capital, IR1=Credit challenge, IR2=Corruption challenge, IR3= Electricity challenge, IR4=Managerial challenge, PEC1=Access to credit, PEC2= Business counseling, PEC3=Joint returnee/government decision-making council, PEC4=Mentoring and matching, $\mathrm{PEC5}=$ Entrepreneurship training, $\mathrm{FC} 1=$ Achieved foreign educational qualifications, $\mathrm{FC} 2=$ Foreign savings.

Figure 2. Path model with latent variables for returnees' entrepreneurship

Source: Field survey, 2017

Table 12. Extract of business climate in Ghana, 2013

\begin{tabular}{|l|c|c|}
\hline Indicator & Ghana & All countries \\
\hline Corruption & & \\
\hline Bribery depth (\%) & 15.7 & 13.7 \\
\hline Firms expected to give gifts in meetings with tax inspectors (\%) & 13.3 & 12.9 \\
\hline Percentage of firms identifying corruption as a major constraint & 41.4 & 32.6 \\
\hline Finance & & \\
\hline Internal finance for investment (\%) & 70.8 & 70.9 \\
\hline Percentage of firms identifying access to finance as major constraint & 58.4 & 26.2 \\
\hline Loans requiring collateral (\%) & 85.3 & 79.5 \\
\hline Regulation and Taxes & & \\
\hline Average number of visits or required meeting tax officials (visits) & 3.1 & 2.7 \\
\hline Percent of firms identifying tax rates as a major constraint & 48.6 & 30.2 \\
\hline Percentage of firms identifying business licensing and permits as a major constraint & 17.9 & 12.9 \\
\hline Infrastructure & & \\
\hline Percentage of firms experiencing electrical outages (\%) & 92.0 & 58.6 \\
\hline Average losses due to electrical outages (\% of sales) & 17.2 & 4.6 \\
\hline Delay in obtaining an electrical connection (days) & 46.2 & 32.0 \\
\hline Percentage of firms identifying electricity as a major constraint & 72.7 & 31.0 \\
\hline
\end{tabular}
Note: Survey based on 720 firms, of which 456 firms are classified as small (less than 20 employees), 203 medium firms (between 20-99 employees) and 61 large firms (100+ employees) respectively.

Source: www.enterprisesurveys.org/data/exploreeconomies/2013/ghana 


\section{Conclusions}

The constraints that affect returnees' investment and entrepreneurship in the home country are seen as important but poorly understood. Using survey data on Ghanaian returnees, this paper analyzed the challenges to the entrepreneurial behavior of returnees in Ghana. Many interesting results have appeared from both the descriptive statistics and the structural equation modeling techniques.

First, the descriptive statistics indicate that the majority of returnees invested in businesses after return, although a significant proportion of these investments are in the service sector, especially IT, finance and insurance, a clue that returnees are investing in wealth-enhancing activities in the service industry. However, results of the structural equation modeling analysis show that those returnee entrepreneurs who established a business on their return encountered difficulties such as inadequate access to credit. As also shown in the path analysis of this study, the existence of social networks is crucial for returnee entrepreneurial activities. This finding is consistent with Åkesson and Baaz's (2015) results that social capital plays a key role for returnees who intends to set up a business in Africa.

In line with what was suggested by the descriptive statistics, returnees who could not invest after return, regarded unavailability of capital as the key constraint in the country, followed by lack of entrepreneurship training. This implies that small business-support programs with mentoring, entrepreneurship training and start-up capital components could be tested to ease challenges on returnee entrepreneurship. Taking the discussion further, it is plausible that enhancing the development of new start-ups could encourage more diaspora Ghanaians who are increasingly prepared to invest in their country of origin (Taylor, 2014).

The results of this investigation show that returnees' entrepreneurship training and access to credit can facilitate the use of returnees' overseas savings, know-how, and skills acquired during migration for entrepreneurial activities. These findings are consistent with OECD's (1996) observation that in the mid-1980s incentives to encourage returnee entrepreneurship was ineffective in Tunisia, but since the early 1990s, there has been an upsurge in return migrants' business investment, indicating that newer incentives appeared to be useful in the country.

Notwithstanding the great contribution of microenterprises to the Ghanaian economy, small businesses are still faced with significant institutional and fiscal constraints that restrict their growth. A casual analysis of the findings of the 2013 business environment study (Table 12 above), for example, indicates that although some aspects of the Ghanaian economy are sufficiently favorable to entrepreneurship, great improvements can be initiated in the areas of access to electricity, where Ghana trails behind economies in sub-Saharan African or other sovereign states. Taken together with the findings shown in this study, this indicates that improvements in the domestic business climate, such as a more consistent application of property law and greater transparency in regulations and licensing requirements, could also enhance the judicious use of the accumulated foreign savings of the increasing number of return migrants to Ghana.

From the empirical evidence studied and the critical literature reviewed, return migration has many positive impacts on Ghana. However, to fully harness return migration and leverage it as the entrepreneurship tool which it has tremendous potential to be, the government of Ghana must incorporate measures to improve the domestic business climate.

\section{References}

Åkesson, L., \& Baaz, M. E. (2015). Introduction. In L. Åkesson, \& M. E. Baaz (Eds.), Africa's return migrants: new developers? (pp. 13-14). London: Nordic Africa Institute.

Alagidede, P., Baah-Boateng, W., \& Nketiah-Amponsah, E. (2013). The Ghanaian economy: An overview. Ghanaian Journal of Economics.

Ammassari, S. (2004). From nation-building to entrepreneurship: The impact of élite return migrants on Côte d'Ivoire and Ghana. Population, Space and Place, 10, 133-154.

Anarfi, J. K., \& Jagare, S. (2005). Towards the sustainable return of West African transnational migrants: What are the options? New Frontiers of Social Policy: Arusha Conference.

Arbuckle, J. L. (1999). AMOS 4.01 [Software]. Chicago: SmallWaters. 
Asenso-Okyere, W. K., Twum-Baah, K. A., Kasanga, A., Anum, J., \& Portner, C. (2000). Ghana living standards survey report of the fourth round (GLSS 4) Accra: Ghana Statistical Service.

Beauchemin, C. (2012). Migrations between Africa and Europe: Rationale for a survey design. MAFE Methodological Notes, INED: Paris.

Bjarnesen, J. (2013). Diaspora at home? Wartime mobilities in the Burkina Faso - Côte d'Ivoire transnational space. $\mathrm{PhD}$ thesis, Uppsala University.

Black, R., \& Castaldo, A. (2009). Return migration and entrepreneurship in Ghana and Côte D'ivoire: The role of capital transfers. Tijdschrift voor Economische en Sociale Geografie, 100, 44-58.

Black, R., Russell, K., \& Tiemoko, R. (2003). Migration, return and small enterprise development in Ghana: A route out of poverty? Sussex Migration Working Paper, University of Sussex: Brighton.

Bollen, K. A. (1989). Structural equations with latent variables. New York: Wiley.

De Bruijn, M., Dijk, R. V., \& Foeken, D. (2001). Mobile Africa: An introduction. In M. De Bruijn, R. V. Dijk, \& D. Foeken (Eds.), Mobile Africa: changing patterns of movements in Africa and beyond (pp. 1-8). Leiden: Bill.

De Haas, H. (2006). Engaging diasporas. How governments and development agencies can support diaspora involvement in the development of their origin countries. International Migration Institute, University of Oxford.

De Haas, H. (2010). Migration and development: A theoretical perspective. International Migration Review, 44, 227-264.

De La Barre, J. (2007). Conditions et perspectives de retour des immigrés au Cap-Vert et mobilisation de la diaspora pour le développement. For the OECD Experts Meeting on Return Migration and Development. Paris: Mimeo.

Dollar, D., Hallward-Drieneir, M., \& Mengistae, T. (2005). Investment climate and firm performance in developing countries. Economic Development and Cultural Change, 54, 1-31.

Dumont, J. C., \& Spielvogel, G. (2008). Return migration: A new perspective. International Migration Outlook, Part III. Paris: OECD Publishing.

Dustmann, C., \& Kirchkamp, O. (2002). The optimal migration duration and activity choice after emigration. Journal of Development Economics, 6, 351-372.

European Commission, (2011), Commission staff working paper: Migration and development, sec (2011) 1353 final Brussels. [Online] Available: https://ec.europa.eu/europeaid/sites/devco/files/swp-migration-anddevelopment-1353-20111118_en_11.pdf. (September 5, 2017)

Grossman, S. J., \& Hart, O. (1986). The cost and benefits of ownership: A theory of vertical and lateral integration. Journal of Political Economy, 94, 691-719.

Gubert, F., De Vreyer, P., \& Robilliard, A. S. (2007). Return migrants in Western Africa: Characteristics and labour market performance. Prepared for the OECD Experts Meeting on Return Migration and Development, Paris: Unpublished.

Hamilton, A., \& Hudson, J. (2014). Bribery and identification evidence from Sudan. Bath Economic Research Paper No.21/14, University of Bath: UK.

Hausmann, R., \& Nedelkoska, L. (2017). Welcome home in a crisis: Effects of return migration on the nonmigrants' wages and employment. Centre for International Development Working Paper No. 330, Harvard University.

Hausmann, R., Klinger, B., \& Wagner, R. (2008). Doing growth diagnostic in practice: A mind book. Centre for International Development Working Paper No. 177, Harvard University.

Hooper, D., Coughlan, J., \& Mullen, M. (2008). Structural equation modelling: Guidelines for determining model fit. Electronic Journal of Business Research Methods, 6, 56-60.

International Organization for Migration. (2004). Glossary on Migration. IOM: Geneva.

International Organization for Migration. (2009). Assisted voluntary return and reintegration programme (AVRRP). IOM: Accra.

International Organization for Migration, (2017), A baseline assessment of household remittances. [Online] Available: $\quad \mathrm{https}: / / \mathrm{www}$.iom.int/news/iom-study-ghana-finds-remittances-nearly-doubled-householdincomes-2016 (August 9, 2017)

Jöreskog, K. G., \& Sörbom, D. (1982). Recent developments in structural equation modelling. Journal of Marketing Research, 19, 404-416.

Jöreskog, K. G., \& Sörbom, D. (2003). LISREL 8.54 for Windows (Computer Software). Lincolnwood: Scientifc Software International.

Kaiser, F. H. (1974). An index of factor simplicity. Psychometrika, 39, 31-36.

Kaplan, D. (2000). Structural equation modelling: Foundations and extensions. Thousand Oaks, CA: Sage.

Kline, R. B. (2005). Principles and practices of structural equation modelling. (2nd ed.). New York: Guilford Press.

Lucas, R. (2005). International migration and economic development: Lessons from low-income countries. UK: Edward Elgar.

Marchetta, F. (2012). Return migration and the survival of entrepreneurial activities in Egypt. World 
Development, 40, 1999-2013.

Mattoo, A., Neagu, I. C., \& Özden, Ç. (2008). Brain waste? Educated immigrants in US labor market. Journal of Development Economics, 87, 255-269.

Mazzucato, V. (2007). Return migration in Ghana: An overview. Report commissioned by OECD, Experts Meeting on Return Migration, DELSA/ELSA/MI/RD (2008)8, Paris: OECD.

McCaskie, T. C. (2008). The United States, Ghana and Oil: Global and local perspectives. African Affairs, 107, 312-332.

Mesnard, A. (2004). Temporary migration and capital market imperfections. Oxford Economic Papers, 56, $242-262$.

Mountford, A. (1997). Can a brain drain be good for growth in the source economy? Journal of Development Economics, 53, 287-303.

Muthén, L., \& Muthén, B. (1998). MPlus (Version 2.01) [Computer Software]. Los Angeles: Muthén \& Muthén.

Naudé, W. (2008). Entrepreneurship in economic development. Research Paper No. 2008/20, World Institute for Development Economics Research, Helsinki.

Nugent, P. (1995). Big men, small boys and politics in Ghana: Power, ideology and the burden of history. New York: Pinter Publishing.

O'Brien, T., Nedelkoska, L., \& Frasheri, E. (2017). What is the binding constraints to growth in Albania? Center for International Development, Harvard University.

Organization for Economic Co-operation and Development. (1996). Migrants: Partners in development cooperation. Paris: OECD.

Oud, J. H. L., \& Folmer, H. (2008). A structural equation approach to models with spatial dependence. Geographical Analysis, 40, 151-166.

Paulson, A. L., \& Townsend, R. (2004). Entrepreneurship and financial constraints in Thailand. Journal of Corporate Finance, 10, 229- 262.

Piracha, M., \& Vadean, F. (2010). Return migration and occupational choice: Evidence from Albania. World Development, 38, 1141-1155.

Plaza, S., \& Ratha, D. (2011). Harnessing Diaspora resources for Africa. In S. Plaza, \& D. Ratha, (Eds.), Diaspora for development in Africa (pp. 1-40). Washington, DC: World Bank.

Ravenstein, E. G. (1885). The laws of migration. Journal of the Statistical Society of London, 48, $167-235$.

Saxenian, A. L. (2002). Silicon Valley's new immigrant high-growth entrepreneurs. Economic Development Quarterly, 16, 20-31.

Schiff, M., \& Özden, Ç (2006). International migration, remittances, and the brain drain. New York: Palgrave Macmillan.

Schoumaker, B., Flahaux, M.-L., Mangalu, M., \& Agbada, J. (2013). Changing patterns of Congolese migration. MAFE Working Paper 19. Paris: Institut National d'Études Démographiques (INED).

Schreiber, J. B., Nora, A., Stage, F. K., Barlow, E. A., \& King, J. (2006). Reporting structural equation modeling and confirmatory factor analysis results: A review. The Journal of Educational Research, 99, 323-338.

Seker, M., \& Yang, J. S. (2012). How bribery distorts firm growth: Differences by firm attributes. Policy Research Paper 6046, Washington, D.C.: World Bank.

Taylor, S. D. (2014). Capitalism and African business cultures. World Institute for Development Economics Research Working Paper 2014/054, Helsinki.

Twum-Baah, K. A. (2005). Volume and characteristics of international Ghanaian migration. In T. Manuh (Eds.), At home in the world? international migration and development in contemporary Ghana and West Africa (pp. 55-77). Accra: Sub-Saharan Publishers.

Wang, J., \& Staver, J. (2001). Examining relationships between factor of science education and student career aspiration. The Journal of Educational Research, 94, 312-319.

Woodruff, C., \& Zenteno, R. (2007). Migration networks and microenterprises in Mexico. Journal of Development Economics, 82, 509-528.

World Bank Enterprise Survey, (2013), Ghana Country Profile. [Online] Available: http://www.enterprisesurvey.org (August 8, 2016)

World Bank. (2015). World Development Indicators 2014, Washington, D.C.: World Bank.

World Bank, (2017), Doing business 2017: Equal opportunity for all. [Online] Available: http://www.doingbusiness.org/ /media/wbg/doingbusiness/documents/profiles/country/gha.pdf (October 31, 2017)

World Economic Forum, (2017), Global Competitiveness Report 2016-2017. [Online] Available: http://www3.weforum.org/docs/GCR20162017/05FullReport/TheGlobalCompetitivenessReport20162017_FINAL.pdf (September 11, 2017)

Zainudin $\bar{A}$., \& Jusoff, K. (2009). The effects of corporate reputation on the competitiveness of Malaysian telecommunication service providers. International Journal of Business and Management, 4, 173-178. 